\title{
Neoliberalism and personal freedoms during COVID-19
}

\author{
James Chalk
}

\begin{abstract}
COVID-19 has put the global healthcare system under intense strain, and different healthcare systems have proven to be more effective than others. In particular, the neoliberal countries of the UK and the United States have proven to be the most vulnerable to a global pandemic, however the more socialist countries of Germany and New Zealand have fared much better. The authoritarian regimes of China and Vietnam have fared significantly better, though this has been at the expense of personal freedoms.
\end{abstract}

This article will assess the impact of coronavirus (COVID-19) on personal freedoms and human rights by first mapping the impact of COVID-19 on human rights in authoritarian countries, such as China and Vietnam, then moving onto the Asia-Pacific region to examine the more liberal and democratic approaches of Taiwan and New Zealand. Finally, we will analyse the impact of coronavirus on European countries, in particular Germany, and then the United States. Broadly speaking, the least neoliberal countries in the world have come through the pandemic in better shape. The impact of neoliberalism on healthcare systems has resulted in a deterioration of healthcare services. Neoliberal restructuring has generally focused on profit rather than healthcare indicators. This neoliberal approach has had a detrimental effect both on access to healthcare services and on the quality of what is affordable for many people.

In December 2019, a new virus called COVID-19 emerged in Wuhan, China. COVID19 rapidly spread to other parts of the country, and from there around the world, despite China's efforts to contain the virus within the province. On January 31st the World Health Organization (WHO) declared a global emergency, citing the growing cases outside of China, with cases emerging in South Korea and Taiwan. By the end of February, the Italian government started to quarantine northern provinces of Vento and the Lombardy region, and by early March nearly 16 million Italians were in lockdown. On March 11th, the WHO declared COVID-19 a pandemic. By the 14th of March, with China seeing its cases fall, Europe was declared the new coronavirus epicentre. Donald Trump declared the coronavirus outbreak a national emergency. By the end of March, the UK had gone into lockdown and cases in New York had skyrocketed to more than 15,0oo. During March, April and May, much of Western Europe remained in quarantine and cases started to fall. By June, restrictions were being relaxed in Europe, although the epidemic continued to worsen in the Western hemisphere. By late September, SAGE was recommending that the UK go into a circuit breaker lockdown for two weeks, as cases again began to surge. In November, the UK government announced a one-month national lockdown until December. Another lockdown was then announced in late December, as the UK began to battle a new strain of the virus.

In 2009, China put forth an 'Equalisation of Basic Public Health Services' (EBPHS), aiming to promote universal healthcare and strengthen public healthcare provision. Chinese authorities consider healthcare as the 'core premise of human development'. China's 2017 Modernization Report put forth a radical proposal aiming at applying engineering 'superhighway practises' to modernise the country's health system, recognising that the country's investment in its health system is low compared to western economies (10 percent as opposed to 15 percent of government expenditure) (Yang et al. 2016:4). The report proposed an 
overhaul of health governance in China based on increased investment, modernisation and technological application aiming at well-being and healthy ageing ((Ma et al. 2019). The recommendations of the report have informed China's health policy since and assisted the country in dealing with the COVID-19 pandemic ((Ma et al. 2019). This, combined with the panopticon model of harsh surveillance, meant that the Chinese Communist Party (CCP) initially tried to cover up the outbreak. The concerns of Dr Li Wenliang, the first COVID-19 whistle-blower, legal scholar Xu Zhiyong, journalist lawyer Chen Qiushi and Wuhan resident Fang Bin were suppressed by authorities and subjected to enforced disappearances (IBAHRI 2020:5).

On January 23rd, Wuhan announced a travel quarantine area, which later expanded to the entire Hubei province, 'a total population of 45 million people' (Liu, Yue and Tchounwou 2020:3). The Huoshenshan and Leishenshan field hospitals were also constructed very quickly. The expanding surveillance state is referred to as the 'Safe City Project' (SCP) - 'The platform collects, integrates, and analyses data from a wide range of sources, such as criminal records, other government databases, networked surveillance cameras, facial and license plate recognition software' (Greitens 2020:6). Part of the SCP is a COVID-19 track and trace application that was launched on January 9th 2020: 'Health Code has been applied in more than 300 Chinese cities and covers at least 900 million users' (Liang 2020:1). Chinese citizens have to provide their name, national ID number, physical condition and facial recognition data, as well as letting GPS track them 24/7. This kind of intrusive monitoring has been widespread for all Chinese citizens for some years, but 'the epidemic has just made that monitoring, which we do not normally see during ordinary times, more obvious' (Kuo 2020).

It is not only high-tech measures that are being used to violate human rights; an army of workers guard entry points to public spaces, ordering residents to log their information to the Health Code App. In February, Sichuan province officials broke up a group playing Mahjong, they then forced the participants to read out an apology, 'We were wrong. We promise there will not be the next time, and we will also monitor others' (Kuo 2020). More worrying is the Chinese government's discrimination against Africans - in early 2020, the CCP in Guangzhou visited homes of African residents, testing them on the spot or forcing them to take a COVID-19 test at the hospital. Some were ordered to self-isolate at home with a surveillance camera and alarms being installed outside of their apartments. This can only be explained by the in-built racism and discrimination against people from African countries. The CCP was successful in controlling COVID-19 because it has invested heavily in its healthcare systems in recent decades, as well as increasing the power of the surveillance state.

Vietnam provides a good example of a country that has dealt with COVID-19 successfully without increasing the power of the surveillance state. Vietnam has a long porous border with China, and has a population of over 95 million people, however Vietnam's Ministry of Health reported only just over 300 cases of COVID-19 by May 20th 2020, and not a single death. The Vietnamese government implemented precautionary measures more than a month before COVID-19 was declared a global pandemic by the WHO - 'early, decisive and transparent actions by the country's leadership, along with the engagement and solidarity of citizens, have been a key to Vietnam's success in combating COVID-19 to date' (Le Thu 2020). The strategy aimed at increasing solidarity in society; the government employed the use of war rhetoric from the beginning and emphasised solidarity in combating the pandemic. In Vietnam, the news coverage has been marked by a prominent narrative: 'Every citizen is a soldier fighting the disease' (Tran 2020). Prime Minister Neguyen Xuan Phuc, portrayed the pandemic as a battle and called on citizens to unite and defeat it. Social distancing and washing one's hands were all portrayed as patriotic acts. Early measures, along with the solidarity of Vietnam's citizens, have meant that the government has not had to implement more drastic measures, such as nationwide lockdowns and 'track and trace' applications. 
Vol. 8, No. 1, 91-99.

Taiwan is 81 miles off the coast of mainland China and was expected to have the second highest number of COVID-19 deaths after China. Taiwan has 23 million citizens, 850,000 of which reside, and 404,000 of which work, in China. Taiwan, in response to the Severe Acute Respiratory Syndrome (SARS) epidemic in 2003, established the National Health Command Centre (NHCC). The NHCC is part of a disaster management centre that focuses on large-outbreak response and acts as the operational command point for direct communications among central, regional and local authorities. As early as January 5 th 2020 , notifications were given to anyone who had travelled to Wuhan in the past 14 days and had a fever or other symptoms. Passengers displaying symptoms were quarantined at home and assessed if medical attention was needed. On January $20^{\text {th }}$, the Taiwan Centre for Disease Control (CDC) activated the CECC for severe special infections, which includes a list of 124 actional items, including border control, identification using technology, quarantining of suspicious cases, and reassurance and education of the public while fighting misinformation. A crucial component of Taiwan's strategy has been the integration of its NHI database with its immigration database. This allows medical providers to facilitate early detection of cases. Taiwan also enhanced its QR code scanning and online reporting of travel history. On November 5th 2020 Taiwan marked 200 days without a domestic COVID-19 infection. Despite the UK variant being ' $67 \%$ to $75 \%$ more infectious than other variants' (Elisabeth 2020:1), Taiwan has only reported 868 cases, the majority being imported. This proves a liberal democratic country can fight the virus without locking down the country or restricting civil rights.

The spread of the COVID-19 pandemic in Europe has led EU member states to adopt a series of emergency measures to contain the virus. Five European countries are in the top ten for COVID-19 deaths, as of January 19th 2021 (Worldometers.info 2020). European governments have resorted to emergency powers to contain the virus, which include limiting internal and international travel; closing schools, universities and shops; limiting outdoor gatherings; and confining people inside their houses. States of emergencies have been declared in ten EU member states. Contact tracing applications are central to government strategies to return to normality, however, they have a massive impact on personal privacy and data protection standards. Track and trace applications 'can identify individuals and reveal highly personal details of people's lives ... Collection and processing of health data, including the publication of information online, poses risks to the safety of affected persons and their communities' (Deloitte 2020:2).

Compared to the harsh but effective efforts of the CCP, European governments are using Bluetooth technology, which is less intrusive than GPS but does have some severe floors. 'The French government launched its StopCovid app at the beginning of June 2020. However, by mid-November, it had only been downloaded some 2.5 million times. So far, only 72 possible risk contacts have been flagged up by the app, while 1,169 users have declared themselves positive' (Thelocal.com 2020). French Prime Minister Jean Castex has admitted he has not downloaded the app. Examples of restrictive measures in the European Union (EU) include Belgium, where the trade union front SETCa have 'heavily criticised two Royal Decrees that were published in the Official Journal beginning of May (and apply until February 28th) whereby one allows provincial governors the opportunity to requisition health workers in the event of a serious staff shortage' (Oliver 2020:1). The measures imposed in Belgium are extraordinary measures that will end on February 28th 2021. In Poland, developments are more concerning for human rights. Although no state of emergency has been introduced, a number of new powers granted to the Polish government were granted at night and in a simplified manner, at maximum speed and without any debate. The governing Law and Justice Party (LJP) has been criticised for taking advantage of the pandemic, especially concerning the 'Stop Abortion Bill' that is a result of a popular initiative. As a result of social distancing rules, mass protesting could not take place, and the 'opposition and women's rights activists criticised the timing of the bill as an opportunistic move to 
bypass democratic scrutiny' (Eșençay 2020:2). COVID-19 has been used by the LJP to strengthen their grip on power at a time when civil society is weaker than normal. With the excuse of dealing with COVID-19, the Polish government turned away from liberalism towards a more authoritarian phase, with the 'reconstruction of the role of the state, the elimination of the pathology of the transition period, and repairing failing state institutions' and a 'change in economic policy consisting of economic patriotism, through weakening the position of the banks and multinational companies.' (Rae and Kulesza 2017:6).

Germany has recorded by far the lowest number of fatalities per million of inhabitants of any other major industrial country. By March 12th, when Germany had around 1,500 infections and three patients had died from COVID-19, the first measures to restrict social contact had been put in place. On March 22nd Germany went into lockdown, although proactive measures by the German public meant that no curfew was put in place and manufacturing and construction companies were not forced to shut down operations. The number of new infections peaked during April, with more than 6,0oo per day, compared to 137,000 per week in the UK. The pandemic hit Germany hard, with more than 2,092,399 people infected (Stafford 2020:1). By April 2oth lockdown was eased, by May 6th schools, restaurants and larger shops were allowed open, and by the end of August concerts, large gatherings (Schneider et al 2020:4) and fairs could take place. The percentage of fatal cases has been remarkably low: 'Germany's fatality rate stood at 1.2 percent, compared with 12 percent in Italy, around 10 percent in Spain, France and Britain' (Stafford 2020:2). There are several reasons behind Germany's performance when compared to other major European countries, such as a well-functioning public health system, which has the highest capacity of intensive care beds in the OECD, at 33.9 per 100,00o, compared to the United Kingdom which has 10.5, as seen in Figure 1. This difference, the so-called 'German exception', can be explained by early and widespread testing and treatment, and plenty of intensive care beds, coupled with

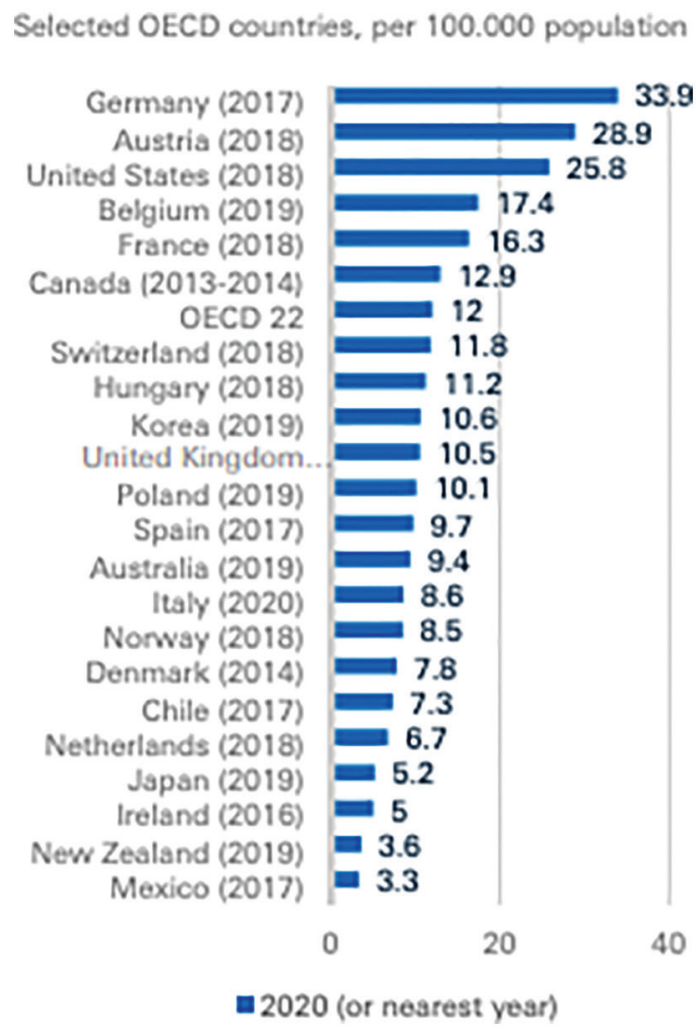

Figure 1 Capacity of intensive care beds 
Vol. 8, No. 1, 91-99.

decisive government action whose social distancing guidelines are widely observed. The German healthcare system quickly provided high numbers of testing kits and sufficient laboratory capacity, 'weekly testing capacity exceeds 1 million, actual numbers have been between 3ook to 40ok in recent weeks' (Landau 2020:8). The German government also moved quickly to protect the economy; in late March it adopted a 'EUR 156bn supplementary federal budget in order to bulk up a "protective shield" against the economic fallout of the coronavirus pandemic' (Landau 2020:10).

In the UK, a decade of austerity has meant the financial squeeze on the health services has been immense; there is a shortage of doctors and nurses, as well as a shortage of hospital beds and medical equipment. As a result of neoliberal austerity, 17,00o hospital beds were lost, and there are more than 40,0oo vacant nurse posts across the NHS (Toynbee and Walker 2020). Dr Richard Horton stated that 'austerity blunted the ambition and commitment of the government to protect its people' (Horton 2020). The UK's health service has one of the lowest levels of doctors and nurses per head than almost any other western country, hence the poor response in dealing with COVID-19. In terms of the surveillance and control measures introduced to stop the spread of the infection, in Western Europe, human rights and personal freedoms have generally been respected, while the Polish state has been moving fast towards becoming an authoritarian state (Gersdorf 2020). Germany has performed remarkably well, especially compared to the UK, because Germany refused to pursue a harsh neoliberal economic model, instead adopting a social market economy with aspects of neoliberalism, called ordoliberalism.

The pandemic has hit the USA harder than any other country globally, with over $24,628,584$ cases and over 408,628 deaths as of January 19th 2021 (Worldometer 2021). This is more than the total American deaths from WW1, WW2, the Korean War, the Vietnam War, both Iraq Wars and the campaigns in Afghanistan. This is due to the impact of American neoliberalism, which has meant the implementation of privatised healthcare services with little support for the vulnerable and low-income citizens. This has resulted in 8.5 percent of its population going without any form of healthcare coverage, and makes the USA one of the only high-income countries that has not achieved universal healthcare coverage (Maizland and Felter, 2020). The Trump administration also failed to implement harsh regulations and often publicly disagreed with the CDCs advice, which has aggravated the pandemics spread. Instead, American neo-liberal policies have neglected the health sector while spending large sums of money, $\$ 750$ billion dollars in 2020, on defence spending (Global FirePower 2020). Figure 2 shows that the US government has spent over \$2.5 trillion on debt interest in the last decade alone, instead of implementing universal healthcare. American neoliberal healthcare also means bills are higher, on average, at \$10,586 per capita compared with $\$ 4,070$ in the UK and \$5,986 in Germany (Peter G Peterson Foundation 2020).

The failure of the US administration to deal with the pandemic should not come as a surprise. A 2017 report titled 'Biological Incident Annex to the Response and Recovery Federal Interagency Operational Plans', authored by Homeland Security, acknowledged that USA healthcare providers may 'experience shortfalls in the availability of personnel, material, space, and systems required to meet the demands on medical and health systems during a contagious disease outbreak' (Department for Homeland Security, 2017:6). In essence, the US government knew that it faced serious shortfalls in the event of a serious health crisis, but because of the neoliberal economic structure chose instead to focus on short-term profits, rather than on protecting the lives of Americans. Neo-liberal economic policy has inflamed racial tensions with the $C D C$, reporting that 'persons of colour might be more likely to become infected with COVID-19, and experience more severe COVID-19associated illness, including a higher level requiring hospitalisation, and have a higher risk for death from COVID-19' (Moore et al. 2020: 1123). The CDC identified county-level disparities in COVID-19 cases among racial and ethnic minorities in counties identified as 


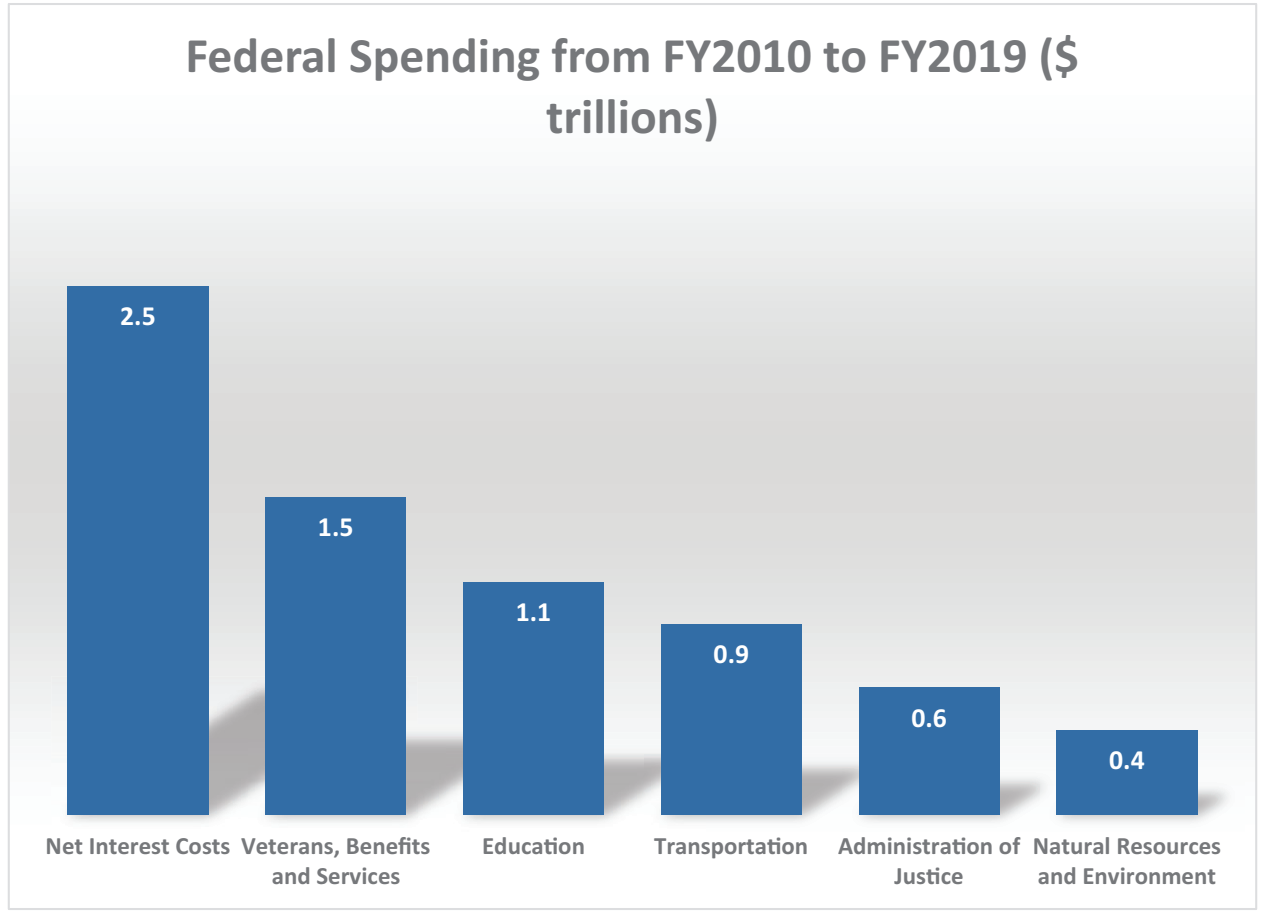

Figure 2 Federal spending from FY2O10 to FY2019 (billions of dollars)

Peter Peterson Foundation 2020

hotspots. 'During June 5-18, 205 counties in 33 states were identified as hotspots; among these counties, race was reported for $\geq 50 \%$ of cumulative cases in $79(38.5 \%)$ counties in 22 states; $96.2 \%$ of these counties had disparities in COVID-19 cases in one or more underrepresented racial/ethnic groups. Hispanic/Latino (Hispanic) persons were the largest group by population size ( 3.5 million persons) living in hotspot counties where a disproportionate number of cases among that group was identified, followed by black/African American (black) persons (2 million), American Indian/Alaska Native (AI/AN) persons $(61,000)$, Asian persons (36,0oo), and Native Hawaiian/other Pacific Islander (NHPI) persons (31,00o),' (Moore et al. 2020).

The case of the US is compared to the less-neoliberal country of New Zealand, which by January 19th 2021, only has 2,262 confirmed cases, with 25 deaths. New Zealand has been so successful in fighting the virus partly because it decided to pursue an eliminated approach rather than a mitigation strategy. 'The two biggest benefits of pursuing an elimination strategy is that you have a few cases and few deaths, and you can get business back up and running. The alternative was that we are stuck with the virus and stuck between mitigation and suppression. Suppression is pretty grim' (Cousins 2020:1). This, combined with contract tracing and testing, means that since January 22nd 2020, more than 150,000 people have been tested in a country of five million. Compared to Vietnam's positioning towards COVID19 as a war, 'The official response here has been guided by the principle that you do not stigmatise and that we unite against COVID-19' (Cousins 2020:2). This language seems to have worked better in a democratic nation. Instead of cutting healthcare spending like the UK, health expenditure as a percentage of GDP rose from 6.8 percent in 1990 to 10.1 percent in 2010 (Cummings et al 2014:5). New Zealand has performed particularly well against COVID-19 because it has not followed the Anglo-American neoliberal economic approach, and has instead invested in its healthcare system. It has adopted an elimination strategy, rather than the Anglo-American strategy of suppression. 
Vol. 8, No. 1, 91-99.

The COVID-19 pandemic has put the various economic and political models across the world under a serious test. Whilst analysing the approaches of a series of countries, it seems they can be grouped into three categories: the authoritarian response, the democratic response and the neoliberal response. The Chinese government was able to combat the virus because of the foundations it laid under the EBPHS, and the strict monitoring of the Chinese people under the Health Code App. The most ineffective response has come from the Anglo-American countries, as both countries have followed neo-liberal economic policy. The UK, in its efforts to restore fiscal discipline, has implemented nearly a decade of austerity, which has blunted the UK's ability to respond to the coronavirus. The US, instead of implementing universal healthcare, has the highest defence spending on the planet. The Trump administration knew in January 2017 that America would be unable to meet the demands of a contagious disease outbreak, yet he chose to ignore the report, treating healthcare as a private good. The strongest approaches have come from the democratic, non-neoliberal approaches of New Zealand, Germany and Taiwan, which have not needed to increase the power of the surveillance states because they continue to treat healthcare as a public rather than private good.

\section{Note}

${ }^{1}$ James Chalk is a third-year student of International Relations at Keele University. xouo3@students.keele. ac.uk

\section{References}

Cousins, S., (2020). New Zealand eliminates COVID-19. The Lancet, 395, pp.1-2.

Cumming, J., McDonald, J., Barr, C., Gerring, Z. and Daube, J., (2014). New Zealand Health System Review. Asia Pacific Observatory on Health Systems and Policies, 4(2), pp.1-244.

Deloitte, (2020). Privacy and Data Protection in the Age of COVID-19. pp.1-4. [Online]. Available at: https://www2.deloitte.com/be/en/pages/risk/articles/privacy-and-data-pro tection-in-the-age-of-covid-19.html [accessed 27 March 2021].

Department for Homeland Security. (2017). Biological Incident Annex to The Response and Recovery Federal Interagency Operational Plans (January 2017). Washington, DC: Department for Homeland Security. Pp 1-132.

Elisabeth, M., (2020). Covid-19: What have we learnt about the new variant in the UK?. British Medical Journal, 371, pp.1-2.

Eşençay, S., (2020). When Covid-19 becomes a Political Ally: Poland's Law on Abortion. LSE Department of Gender Studies, pp.1-5. [Online]. Available at: https://blogs.lse.ac.uk/ gender/2020/06/24/when-covid-19-becomes-a-political-ally-polands-law-on-abortion/ [accessed 27 March 2021].

Gersdorf, M., (2020). Polish State Becoming Authoritarian. [Online]. BBC News. Available at: https://www.bbc.co.uk/news.world-europe-52489336 [accessed 24 November 2020].

Global FirePower, (2020). Defence Spending By Country 2020. [Online]. Available at: https:// www.globalfirepower.com/defense-spending-budget.asp [accessed 21 November 2020].

Greitens, S., (2020). Dealing with Demand for China's Global Surveillance Exports. Global China, pp.1-16. [Online]. Available at: https://www.brookings.edu/research/dealing-withdemand-for-chinas-global-surveillance-exports/ [accessed 27 March 2021]. 
Horton, R., (2020). Coronavirus Is the Greatest Global Science Policy Failure in A Generation. The Guardian. [Online]. Available at: https://www.theguardian.com/commentisfree/2020/ apr/og/deadly-virus-britain-failed-prepare-mers-sars-ebola-coronavirus [accessed 18 November 2020].

International Bar Association's Human Rights Institute (IBAHRI), (2020). Chinese authorities' use of Covid-19 pandemic to restrain human rights lawyer condemned by human rights defenders. pp.1-5. [Online]. Available at: https://www.ibanet.org/Article/NewDetail. aspx?ArticleUid=10d1e82a-bc1b-4d6f-8c7b-b34443fc31d5 [accessed 27 March 2021].

Kuo, L., (2020). 'The New Normal': China's Excessive Coronavirus Public Monitoring Could Be Here To Stay. The Guardian. [Online]. Available at: https://www.theguardian.com/ world $/ 2020 / \mathrm{mar} /$ o9/the-new-normal-chinas-excessive-coronavirus-public-monitoringcould-be-here-to-stay [accessed 24 October 2020].

Landau, D., (2020). COVID-19: Crisis Resilience Made in Germany. Deutsche Bank, pp.1-20 [Online]. Available at: https://www.dbresearch.com/PROD/RPS_EN-PROD/ PRODoooooooooo509268/COVID-19\%3A_Crisis_resilience_made_in_Germany.pdf?undefined\&realload $=f \sim \mathrm{C}_{55} \mathrm{CP} \sim 8 \mathrm{xONiUbZQ} 2 \mathrm{CCf} 6 \mathrm{jqtXVS} 3 \mathrm{EG} 6 \mathrm{gmRBfXSTrxbZZVhA3}$ YnESIgqRv QhXxfD7iFyıyarLhoiNP13YjWRAQ== [accessed 27 March 2021].

Le Thu, Huong, (2020). Vietnam's Successful Battle against Covid-19. Council of Foreign Relations. [Online]. Available at: https://www.cfr.org/blog/vietnams-successful-battleagainst-covid-19 [accessed November 15th 2020].

Liang, F., (2020). COVID-19 and Health Code: How Digital Platforms Tackle the Pandemic in China. Social Media + society, 6(3), pp.1-5.

Liu, W., Yue, X. and Tchounwou, P., (2020). Response to the COVID-19 Epidemic: The Chinese Experience and Implications for Other Countries. International Journal of Environment Research and Public Health, 17(7), pp.1-6.

Ma, X., Wang, H., Yang, L., Shi, L and Liu, X., (2019). Realigning the Incentive System for China's Primary Healthcare Providers British Medical Journal 365(12406). [|Online]. Available at: https://www.bmj.com/content/365/bmj.12406 [accessed 27 March 2021].

Maizland, L. and Felter, C. (2020). Comparing Six Health-Care Systems in A Pandemic. Council on Foreign Relations. [Online]. Available at: https://www.cfr.org/backgrounder/ comparing-six-health-care-systems-pandemic [accessed 29 May 2020].

Marzocchi, Ottavio, (2020). The Impact of Covid 19 Measures on Democracy, the Rule of Law and Fundamental Rights in the E.U. Policy Department for Citizens'Rights and Constitutional Affairs, pp.1-10. [Online]. Available at: https://www.europarl.europa.eu/thinktank/en/ document.html?reference=IPOL_BRI(2020)651343 [accessed 27 March 2021].

Moore, J. T., Ricaldi, J. N., Rose, C. E., Fuld, J., Parise, M., Kang, G. J., Driscoll, A.K., Norris, T., Wilson, N., Rainisch, G., Valverde, E., Beresovsky, V., Brune, C. A., Oussayef, N. L, Rose, D. A., Adams, L. E., Awel, S., Villanueva, J., Meaney-Delman, D., Honein, M. A., COVID19 State, Tribal, Local, and Territorial Response Team, (2020). Disparities in Incidence of COVID-19 Among Underrepresented Racial/Ethnic Groups in Counties Identified as Hotspots During June 5-18, 2020 - 22 States, February-June 2020, Morbidity and Mortality Weekly Report 69(33), pp. 1122-1126.

Oliver, N., (2020). Can a Virus Undermine Human Rights? The Lancet Public Health, 5 (5), pp.1-2. 
Vol. 8, No. 1, 91-99.

Peter G Peterson Foundation, (2020). Selected Charts on The Long-Term Fiscal Challenges of The United States. New York, USA: The Peter G Peterson Foundation. [Online]. Available at: https://www.pgpf.org/sites/default/files/PGPF-Chart-Pack.pdf [accessed November 2020].

Rae, G. and Kulesza, C., (2017). The Law and Justice Party and Poland's Turn to the Right. Transform Europe, pp.1-9. [Online]. Available at: https://www.transform-network.net/fileadmin/user_upload/raekulesza_paper_final_19_01_2017.pdf [accessed 27 March 2021].

Schneider, S., Becker, S., Boettcher, B., Heymann, E. and Schattenberg, M., (2020). COVID19: Crisis resilience made in Germany. Deutsche Bank Research, pp.1-20. [Online]. https:// www.dbresearch.com/PROD/RPS_EN-PROD/COVID-19\%3A_Crisis_resilience_made_in_ Germany/RPS_EN_DOC_VIEW.calias?rwnode=PRODoooooooooo445454\&ProdCollection =PRODoooooooooo509268 [accessed 27 March 2021].

Stafford, N., (2020). Covid-19: Why Germany's case fatality rate seems so low. British Medical Journal, 369(8241), pp.1-2.

Thelocal.com, (2020). Which European Countries' Coronavirus Phone Apps Have Had The Most Success? [Online]. Available at: https://www.thelocal.com/20200909/do-any-ofeuropes-coronavirus-phone-apps-actually-work [accessed October 24th 2020].

Toynbee, P. and Walker, D., (2020). The Lost Decade: 2010-2020. London: Guardian Faber, pp.1-368.

Tran, Jueni Duyen, (2020). Vietnam's war on Covid-19. Journal of International Affairs. [Online]. Available at: https://jia.sipa.columbia.edu/online-articles/vietnam\%E2\%8o\%99swar-covid-19 [accessed October 10th 2020].

Worldometers.info, (2020). 'Coronavirus Update (Live)'. [Online]. Available at: https:// www.worldometers.info/coronavirus/ [accessed 24 October 2020].

Yang, L., Sun, L., Wen, L., Zhang, H., Li, C., Hanson, K. and Fang, H., (2016). Financing strategies to Improve Essential Public Health Equalization and its Effects in China. International Journal for Equity in Health, 15(194), pp.1-12. 